\title{
Global Sign, Shared Meaning? Kobe Bryant's Life and Its Representation from the USA to France
}

\author{
Yann Descamps ${ }^{1}$
}

Accepted: 5 June 2021 / Published online: 3 July 2021

(c) The Author(s), under exclusive licence to Springer Science+Business Media, LLC, part of Springer Nature 2021

\begin{abstract}
This article examines the media representation of Kobe Bryant's life in the media and his meaning as a global sign, both in France and the USA. It analyzes the representation of Bryant in French magazine 5 Majeur to highlight the specificities of the French media coverage of the NBA. In doing so, this article reconsiders Kobe Bryant's story, its meaning to people in the USA and France, but also what it shows about evolving societal communications.
\end{abstract}

Keywords Media $\cdot$ Communication $\cdot$ Myth $\cdot$ Storytelling $\cdot$ Ethos $\cdot 5$ Majeur

\section{Introduction}

It was a quiet Sunday evening. French sports fans were preparing to watch their traditional Sunday night game when phones started buzzing and the news started spreading. These same fans turned to social media and the website of French sports newspaper L'Équipe. Iconic French sports television show Stade 2 announced the death of "a global sports legend" (YouTube "Stade 2", 2020). ${ }^{1}$ On Bein Sports, the official broadcaster of the National Basketball Association on French television since 2011, the Sunday Night Live show, usually dedicated to early Sunday NBA games, featured the main announcers discussing the news with tears in their eyes (YouTube "Sunday Night Live", 2020). The following day, French sports newspaper L'Équipe featured Bryant on its cover, with the title "l'Étoile Bryant"-Bryant, the Star (L'Équipe no. 23,924, January 27, 2020). Bein Sports daily show NBA Extra turned into a tribute to Bryant's career, with all the hosts dressed in black, and his

\footnotetext{
1 The author translated all quotes from French sources.

Yann Descamps

yann.descamps@univ-fcomte.fr

1 Department of Sport Studies, Research Center C3S “Culture, Sport, Santé, Société” Université Bourgogne Franche-Comté, (E.A. 4660), Besançon, France
} 
death being portrayed as a "Where were you?" moment (YouTube "NBA Extra", 2020). Canal+journalist George Eddy, the iconic French NBA announcer since 1985, discussed Bryant's impact around the world, from the USA to China to France (YouTube "Canal+", 2020). On January 28, L'Équipe once again dedicated its cover to the news, with the title "Le monde pleure Kobe"-The World Mourns Kobe (L'Équipe no. 23,925, 2020). On the Saturday, February 1, its supplement featured an article on Gianna Bryant and the father-daughter relationship (L'Équipe Mag no. 1,959, 2020).

The death of Kobe Bryant in a helicopter crash left a community of French sports fans-athletes and journalists included-in disbelief. Bryant starred in the NBA at a most fortuitous time, after the Michael Jordan era, as the Internet coverage of the league, along with the rising television coverage, gave more and more visibility to a league eager to keep pace with globalization. Most of the NBA sportscasters in France grew up watching and idolizing Jordan, and Bryant had been their go-to story for years, until his retirement in 2016. And even after his career ended, he remained a relevant storyline in the French sports media. Bein Sports announcer Xavier Vaution said, "He had been part of our lives for more than twenty years" (YouTube "NBA Extra", 2020). French basketball magazine 5 Majeur editor Pascal Silvestre wrote, "He was our lighthouse, our compass. When we were lost, Kobe would come to our rescue. With time, we came to the point where we would make him part of us, part of our heart family. Yes, in his own unique way, without trying or even being willing to be, Kobe was in our hearts" (5 M HS no. 23). From his early years and first NBA titles in the 2000s to his 60-point final game, Bryant had become "Kobe," a global sign full of meaning. His death shone a light upon this meaning. People around the world mourned, discussing Bryant's death on social media, or painting murals of him and his daughter all around the world (@kobemurals). On social media, former NBA player Dwyane Wade shared his thoughts on the day of the tragedy, saying, "I know we all feel the same way about such a great leader, such a great champion, such a great person. If you get a chance to really know Kobe, ain't nobody better, man." NBA Extra hosts agreed (YouTube "NBA Extra", 2020). People felt the same way all around the world. Or did they?

In the American media, while people mourned Bryant and expressed sadness and sorrow at the news of his death, many journalists underlined his complex legacy, both as an athlete and a human being, from his ultra-competitive spirit to the 2003 sexual assault case, portraying him as an evolving sign (Dionne, 2020; King, Brennan and Blackistone, 2020; Newberry \& La Ganga, 2020; Owens, 2020; Stein, 2020; Thomas, 2020). Yet, in France, the media coverage of Bryant's death left virtually no place for complexity. While the sports images and anecdotes brought forward by French reporters mirrored those highlighted in the US media, the darker, more political side of Bryant's life was mainly omitted. Yes, France was mourning a global icon, but did the French mourn the same version of Kobe as presented in the US media?

Contemporary professional sport is a mediated spectacle which gives birth to narratives. These media-constructed "myths" and "legends"- these words are being constantly tossed around in the media-actually carry meaningful discourses that allow us to come to grips with issues that our societies often try to avoid discussing. 
In the signifying world of sports, Kobe Bryant was - and still is - a sign. Even more than that, he could be described as a myth, i.e., a system of communication, messages, and a form attached to concepts and linked to a specific significance (Barthes, 1957). Bryant's body, moves, image, and name were linked to several concepts. Studying the media coverage of his career and death in a context of intercultural communication where the NBA communicates effectively across cultures, turning earth into a "global village" (Dues \& Brown, 2004, 87-89), allows us to highlight his different meaning depending on places-especially in France, a country with a rich history of basketball and strong connection to the NBA (Archambault et al., 2007). Yet, to what extent does the media coverage of Kobe Bryant's career and death in France highlight the impact of the evolution of media and communication over the construct of shared meaning in our societies?

\section{Research Design}

This article focuses on the manner in which Bryant is depicted in the French media over the course of his 20-year career as a Los Angeles Laker, one of American sports most storied franchises, as well as the years following his retirement in $2016 .^{2}$ At the same time, various forms of American media such as online press articles, obituaries to Sports Illustrated covers, biographies, and scholarly articles are used for comparison purposes. ${ }^{3}$ The juxtaposition of Bryant's media representation in the US vis-vis France may tell us something about the two countries as well as Bryant's iconic stature. This work uses Stuart Hall's view of representation as the production and exchange of shared meaning (Hall, 1997, 1). It considers Bryant's media coverage as language in the sense of what Hall describes:

Language is the privileged medium in which we "make sense" of things, in which meaning is produced and exchanged.

\footnotetext{
2 This analysis of the French media coverage of Bryant focuses on French basketball magazine 5 Majeur, while also taking into consideration the coverage of Bryant's death and tributes to his career in the main French sports media, from national sports newspaper L'Équipe and its supplement L'Équipe Mag to sports television shows Stade 2, NBA Extra and Canal+'s sports news program.

3 In order to seize the meaning of Bryant as a sign in American society, beyond his representation as a player on television or in advertisements (to which French audiences have been exposed through their own sports television shows), this study took into account the press articles published at the time of his death in newspapers such as the New York Times (Stein, 2020) and the Los Angeles Times (Holter et al., 2020; Newberry and La Ganga, 2020), websites Yahoo! Sports (Owens, 2020) and NPR (King et al., 2020), and magazines The New Yorker (Thomas, 2020) and Time Magazine (Dionne, 2020). Also, along with the covers of magazine Sports Illustrated featuring Bryant, it analyzed two biographies, Mark Heisler's Kobe and the New Lakers Dynasty (2009) and Roland Lazenby's Showboat: The Life of Kobe Bryant (2016). Last, to compare with the lack of studies discussing Bryant by French scholars (Sudre, 2013; Trespeuch, 2014), it considered scholarly articles and book chapters from various authors published in the USA (Boyd, 1997, 2003; Leonard, 2004; Johnson, 2005; Markovitz, 2006; Baily, 2007; Franiuk et al., 2008; Kennedy, 2010; Leonard and King, 2011; Mirpuri, 2011; Leonard, 2012; Thwaites et al., 2012; Meng and Pan, 2013).
} 
Language is able to [construct meaning] because it operates as a representational system. In language, we use signs and symbols-whether they are sounds, written words, electronically produced images, musical notes, even objects- to stand for or represent to other people our concepts, ideas and feelings. Language is one of the "media" through which thoughts, ideas and feelings are represented in a culture. Representation through language is therefore central to the processes by which meaning is produced (1).

This research also considers the part played by journalists in relaying this shared meaning, speaking the same language as the American media, or producing a slightly different one:

It is participants in a culture who give meaning to people, objects and events. .. It is by our use of things, and what we say, think and feel about them - how we represent them - that we give them a meaning. (3)

In order to communicate these meanings to other people, the participants to any meaningful exchange must also be able to use the same linguistic codesthey must, in a very broad sense- - "speak the same language". They must also be able to read visual images in roughly similar ways (6).

This work offers "readings" of Bryant as a global text, through a critical analysis of his coverage, while "engaging with power as a central focus for understanding social life" (Birrell \& McDonald, 2000, 3). This critical analysis of the representation of Kobe Bryant also follows in the footsteps of Ronald L. Jackson's work on the representation and meaning of the Black masculine body (2006), Miles White's work on race and the performance of masculinity (2011), David J. Leonard's work on the representation of African-American athletes (2004; 2012; Leonard \& King, 2011), studies by Mary G. McDonald (2001) and David L. Andrews (2001) on Michael Jordan as a signifier, and Todd Boyd's work on the meaning of AfricanAmerican basketball players in popular culture (1997; 2003).

In order to study Bryant's representation in France, this article focuses on elements from different media regarding the coverage of Bryant's death, along with a study of the coverage of Bryant's life and career in French basketball magazine 5 Majeur. Founded in 1991, 5 Majeur has followed Bryant's career from start to finish and released two special issues in tribute to his life after his death. In the words of Roland Barthes, it could be described as a "transmission canal" (1982, 9). Among the French media, 5 Majeur is the only media which covered Bryant's entire career, from 1996 to 2016 and beyond (Rebillard, 2003). Using Christian Vivier and Brice Monier's semio-historical analysis of Maxi Basket, another (now defunct) basketball magazine, as a source of inspiration (Monier \& Vivier, 2012; Vivier et al., 2008), this study "examines" 5 Majeur's front covers, along with articles dedicated to Bryant, over a 22-year period-from 1999 to $2021{ }^{4}$

\footnotetext{
${ }^{4}$ Due to the COVID-19 pandemic, the author was not granted access to the archives of the magazine at the Bibliothèque Nationale de France. He turned to private collections and the magazine's own (incomplete) archives which allowed to cover a 21-year period, with only the first 3 years of Bryant's career missing. However, these years were dominated by another icon-Michael Jordan.
} 
In France, the focus has been on either (re)telling the story of his life, relaying media narratives, translating biographies, or studying Bryant as a case study in image management (Trespeuch, 2014). In the USA, beyond biographies, most researches have focused on the sexual assault case and its impact on Bryant's image, or how it intertwined with race (Johnson, 2005; Markovitz, 2006; Baily, 2007; Franiuk, Seefelt, Cepress and Vandello, 2008; Kennedy, 2010; Thwaites et al., 2012; Meng \& Pan, 2013). This work highlights the cultural significance of Bryant and his representation in the media, and what it says about the state of communication within our societies. Like Anoop Mirpuri, it explores "the narrative construction of Kobe Bryant" $(2011,96)$, and discusses issues of race in relation to Bryant. It also carries a global dimension and assesses the power and political dimension of a global story, and the importance of acculturation (Bastide, 2000, 2001) and cultural transfers. Here, sports media are portrayed as a "gateway of globalization"-i.e., complex spaces in which discourses evolve and influence audiences and collective imaginations, thus carrying politically charged messages (Espagne, 2012), even in stories or covers which "look" apolitical.

This study opens up on the power of stories. Like Walter Fisher, it considers them as ways of communicating and reasoning (Dues \& Brown, 2004, 51). It also reads them within a political context, as Evan Cornog does (2004). Here, storytelling is seen as a "technique of communication, control and power" (Salmon, 2007, 12), and discourse as a terrain of struggle, and "politicized, power-bearing language" (Fiske, 1999, 3). Moreover, this research tackles the part played by stories in "building and maintaining mutuality and emotional bonds", and thus building communities (Nathan, 2013, 5).

Beyond that, this study opens up on the evolution of media, and communication in general, inspired by Lawrence Wenner's (1989) and Andrew Billings, Michael Butterworth, and Paul Turman's (2012) studies of sports and the media; Bolter and Grusin's use of remediation (1998); Henry Jenkins' work on transmedia storytelling (2006); Emilio Fernandez Peña's work on social media (2011); Benoit and Billings' work on mass communication (2020); and Dan Nimmo and James E. Combs' theory on mediated political realities (1990).

In his study of the Super Bowl coverage, Wenner highlighted that mediated sport provides "somewhat uniform fantasies" $(1989,177)$. These uniform fantasies give life to America's founding myths-regardless of their actualization in society. As Nimmo and Combs underlined, by being created and propagated, these fantasies take on "an aura of truth" $(1990,11)$, until the fantasy becomes the reality as created by communication (3). Sut Jhally also wrote that "sports are an explicit celebration of the idealized structures of reality" (Wenner, 1989, 160). Through its covers and articles, and in its coverage of the Kobe story, 5 Majeur constructed a fantasized version of the idealized structure of reality that is the NBA. It also arguably constructed a fantasized, idealized version of the Kobe myth. This research thus uses a discursive approach, as it is "concerned with the effects and consequences of representation-its politics. It examines not only how language and representation produce meaning, but how the knowledge which a particular discourse produces connects with power, regulates conduct, makes up or constructs identities and 
subjectivities, and defines the way certain things are represented, thought about, practiced and studied" (Hall, 1997, 6).

\section{"Notre Kobe": an Analysis of the French Media's Coverage of Kobe Bryant's Career and Death}

As some of the articles discussing Bryant's legacy on the days following his tragic death showed, in the UDS, Bryant's media coverage had given birth to lots of stories, leading up to a complex narrative. A look at the Sports Illustrated covers of Bryant (from 1998 to 2020) offers a glimpse of his evolving significance as a sign, from the young, smiling prodigy having fun with Laker legend Magic Johnson (SI Vol. 88 no. 17), to his police mugshot (SI Vol. 99 no. 3), to his "moment" when he reconquered the NBA title (SI Vol. 110 no. 25), to his portrayal as "the last Alpha Dog" (SI Vol. 119 no. 16) and Laker legend hovering over LeBron James' performances in LA (SI Vol. 129 no. 2). Yet, has this narrative crossed the Atlantic without losing its meaning and complexity? Analyzing the 5 Majeur's coverage of Kobe Bryant's career enables one to identify the originality of the French take on American sports, along with the signifying differences in the way Bryant was portrayed. His story began at the tail end of Michael Jordan's Bulls years (during which the latter saturated the French basketball media scene), when the NBA was already a global product, whose globalization was on its way to exploding over the next several years. From 1999 to 2020, Bryant has been one of the French basketball media's go-to stories.

From 1999 to the 2004 NBA Finals with the Shaquille O'Neal-led Lakers, Bryant was featured on $40 \%$ of the covers (see Table 1). From 1999 to 2011, he appeared on $32.5 \%$ of the covers. And over the course of his 20 -year playing career, he was featured on nearly $25 \%$ of the magazine covers and almost $18 \%$ of the posters featured in each magazine. Interestingly enough, these numbers only drop to nearly $22 \%$ of the covers and almost $16.5 \%$ of the posters when we examine the period from 1999 to 2021 . So, for more than 20 years, as a young prodigy, an NBA champion or a retired legend, Kobe Bryant has been a relevant story, used by the magazine to showcase its product-NBA basketball—and attract customers through iconic images featured on the covers (Monier \& Vivier, 2012). His "legend" was only reinforced by his usual portrayal in posters for the French kids to staple on their bedroom walls. These figures tell a powerful story about Bryant's impact in France. However, looking at the principal traits of his representation, both in images and articles, highlights the French media's approach to Bryant as a sign. Indeed, 5 Majeur editors and writers played several parts. In turn, they were fan boys, amateur psychologists, relays, and critics of the American press. 


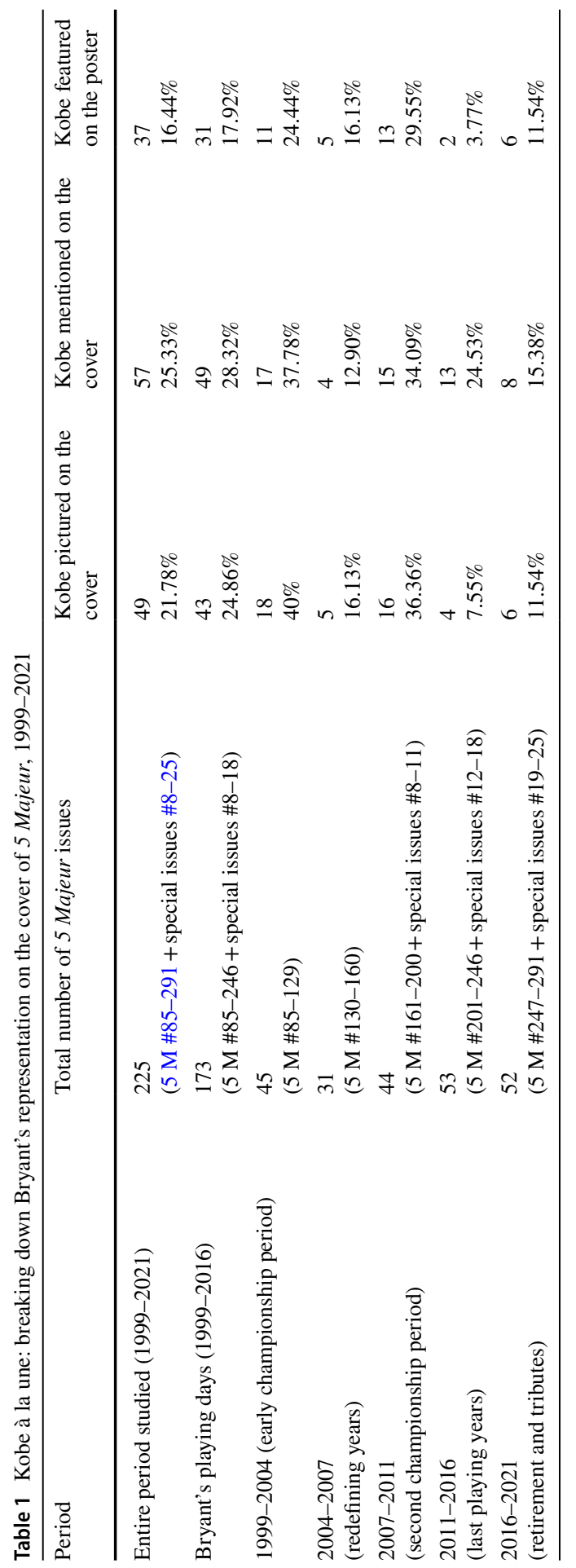


Fig. 1 "Notre Kobe": cover of 5 Majeur's special issue \#23 following Bryant's death, February 2020. https://www.aboriva.com/ hors-serie/2166-5-majeur-23. html

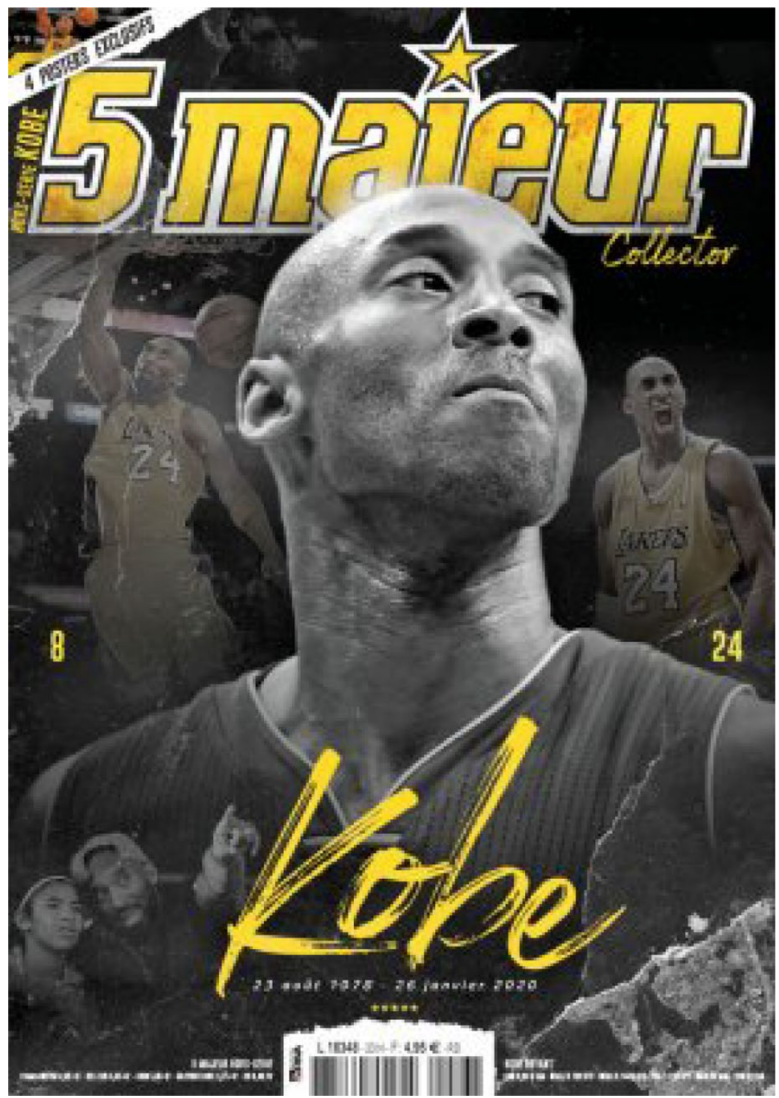

\section{Poster Boy and Fan Boys}

Multiple factors can explain Kobe Bryant's major presence on the covers and posters of 5 Majeur. His team was winning, and his team played in Los Angeles - the motion picture capital of the world and a city that stands as a myth from the perspectives of many French writers. Despite the presence of Shaquille O'Neal, another all-time great, the magazine chose to emphasize Bryant. This infatuation continued up until his retirement and culminated in a special issue following his death (Fig. 1). Over the last 20 years, Bryant received the most extensive media coverage of any athlete. He has been portrayed as a genius, a winner, a champion, a legend, equal to Magic Johnson and Michael Jordan: "Just like any genius, Kobe focuses on details first, to paint the most accomplished fresco. $\mathrm{He}$ works hard at practice, he makes his body tolerate the pain, he studies films... We could think he is totally obsessed with his work which smells of sweat and Gatorade" (5 M no. 192, 27). Just like Jordan, he embodied "the fusion of the formal and the vernacular," as Boyd wrote $(1997,111)$. This was widely underlined by the French magazine, which focused on both his technical skills and his 
improvisations. Most of all, he was celebrated as an alpha male, a tough player, with a tremendous will to win-the latter the subject of countless articles. The commemorative issue crystalizes this portrayal of Bryant. When it was time to sum up his career, 5 Majeur chose five iconic moments to highlight his career, two of which featured his offensive prowess (his 81 points on January 22, 2006, against the Toronto Raptors and his 61 points against the New York Knicks at Madison Square Garden on February 2, 2009), while the other two focused on his mental toughness (when he refused to flinch as Matt Barnes faked throwing the ball at his head on March 7, 2010), and on April 12, 2013, when he shot his free throws, despite having a ruptured Achilles, which, taken together, form the basis of the "Mamba Mentality," which was highlighted in Bryant's speech at the ESPYs on July 13, 2016-the last date chosen by the magazine ( 5 M Special Issue, 53). Bryant was admired and loved, as the magazine's titles "Beyond Grief" (4) and "Dear Kobe" (65) illustrates. Yet, even though the pages of this special "Kobe" issue was saturated with praise, throughout his career, just like in the USA, he was at times both celebrated and criticized.

\section{Two-Dollar Shrinks}

Most of the articles in the French publication dedicated to Bryant mixed praises of his unlimited talent and sharp criticism aimed at his selfish style of play (5 M no. 100). As a sign, he was both a basketball ideal and the worst version of team sporti.e., an individualistic player. Facing this basketball Janus, the magazine started a love-hate relationship with Bryant and constantly tried to decipher the man behind the myth and look for "the real Kobe" (5 M no. 122), resolving to "two-dollar psychology," to their own admission (5 M no. 134, 76-77). Thus, Kobe was portrayed as "an enigma" (5 M no. 125), a psychologically complex character, as in 5 Majeur no. 100, when he was portrayed as "all alone in the world, beloved by fans, yet lonely with the Los Angeles Lakers, an unconventional young man with a complex, solitary character, who works like crazy, a loner, a bit of a nerd, Shaq's opposite" and a ballhog. Many articles wondered who the real Kobe was, and whether we should love him or hate him, as in issue no. 147 titled "For or Against Kobe?", in which he was described as "enigmatic and controversial" (5 M no. 147, 4), "probably the all-time best from a technical standpoint, humanly dubious and yet a basketball player worthy of all praises" (20), and, on the other hand, a "selfish genius," forgetting about some sporting values (21), "hero and villain" at the same time to many NBA fans (23). During the Colorado scandal, Bryant was portrayed as a tortured character, saddled with schizophrenia, who needed therapy. 5 Majeur writers tried to unearth the meaning of the Laker player. They actually opened the door to a dual reading of him, allowing both Kobe lovers and haters to find some truth to what they were reading - a strategy which was also used by the American media. 


\section{Relaying the American Narrative}

Another decisive trait regarding the French media coverage of Bryant's life and career is that most storylines came from what was previously released or discussed in the American media. This is linked to the particularities of French sports magazines covering the NBA from the 1990s to the 2010s. Throughout this period, French fans had little media contact with the NBA and the American media. They were limited to watching a couple of NBA games a week (in the middle of the night) and following the results, along with the league's corporate coverage of the news, on the Internet. But if a different perspective is what they sought, they turned to magazines such as 5 Majeur, whose special correspondents lived in the USA and were privy to and no doubt influenced by TV shows, radio talk shows, and newspapers by American beat reporters. What they did was mainly remediate the American media narrative around Kobe Bryant's life and career (Bolter \& Grusin, 1998), from the Kobe-Shaq feud, to the endless comparisons with Michael Jordan and then LeBron James, the Colorado scandal, and his athletic feats. Actually, the five dates symbolizing Bryant's life according to 5 Majeur were all (but the 81-point game) linked to American media and popular culture: his 61 points were also linked to his work with Spike Lee on the ESPN documentary Kobe Doin' Work (Lee, 2009), the Matt Barnes episode was on heavy rotation on SportsCenter, the free throws were used by Nike in an iconic commercial (YouTube "You Showed Us", 2013), and the Mamba Mentality speech was... at the ESPYs. So almost all the Kobe stories that comprised the Kobe narrative were reflections of American stories.

\section{Taking a Step Back?}

Cultural transfers are signifying. Stories can gain some meaning-or lose some. In the case of 5 Majeur, both existed. On the one hand, the magazine seemed to take a step back from the sports spectacle that is the NBA (as NBA games are described as "spectacles, just like the concerts of established rock stars" in issue no.192), or from some aspects of American society, from its blinded celebration of sports stars to its media frenzy and harsh criticism of these "role models." At the start of the 2001 season, 5 Majeur writers were hoping Bryant would not "be swallowed by the huge media machine of the City of Angels," as they were rooting for the young, talented Laker (5 M no. 99). Throughout the early 2000s, they mocked the Shaqand-Kobe "Vaudeville" and its coverage (5 M no. 107). America, Los Angeles, and Hollywood, "the land of cinema and excesses of all kinds, the mandatory address of the biggest stars on the planet" (5 M no. 192, 27), were described both as a dream and "a mess" (5 M no. 129), and harshly criticized for their inauthenticity. Even to this day, Los Angeles remains "the city of cinema and gangs" (5 M no. 291). Also, "Melodrama [was] part of the Laker culture" (5 M no. 186, 19), and "Lakerland" was described as "the empire of B.S. and waffle" (5 M no. 143, 67).

While mostly relaying the American perspective, the writers occasionally presented different takes, often brimming with anti-Americanism-a way 
of thinking with a deeply rooted history that resurfaced in France during the George W. Bush presidency-and some "we the French know better" attitude that the French media sometimes express when covering foreign countries. This was particularly the case in the context of this love-hate relationship between France and the USA, two nations which have portrayed themselves as enlightened, torch-bearing beacons for the rest of the world (Roger, 2002). The writers curiously celebrated Bryant's "mutation" in the aftermath of the Colorado scandal, as "Mister Perfect, a model of political correctness, turned his back on self-righteous America" (5 M no. 125, 60). More than that, they portrayed him as the product of Bush's America: “America has drawn Kobe just like itself. The country of disastrous W. Bush has rubbed off on the Laker's natural brutality until turning him into a Terminator in shorts" (5 M no. 147, 21). On the other hand, the magazine romanticized the American Dream and Kobe Bryant's life and career in order to build a hero figure, failing to tackle or deconstruct important issues that surfaced during Bryant's career. Lastly, the issue of race was largely left unexplored, surfacing only once, when the racial composition of the jury Bryant would have faced in Colorado, was raised. The magazine preferred to focus on crafting the figure of a misunderstood genius.

This analysis of 5 Majeur's rhetoric showed that Bryant's body, moves, image, and name were linked to several concepts. In France, he embodied America's brilliance and world dominance, as well as American arrogance, both in politics and sports. He embodied Hollywood and a fantasized image of Los Angeles. He embodied the quest for excellence and the will to emulate perfection. 5 Majeur is a brilliant example of the remediation of the Kobe story, with some minor yet signifying changes in meaning. Indeed, the French Kobe story was somewhat simplified, romanticized, and yet at times more critical than the US media. Kobe was turned into a novel character, as player-and-coach-turned-TV-colorcommentator Jacques Monclar said on Bein Sports after his death: "His whole story has been romanticized, with the Shaq saga, the Phil Jackson relationship, his 81 points, Colorado, his redemption, his Olympic story where he was the one they turned to when they felt the heat against Spain, where he was the one getting the ball and scoring the crucial basket... He always took responsibility. He was waking up at 5:30 in the morning to train before practicing with the others, he had a Stakhanov-like demanding, precise nature, and that's what we found in his animated short film Dear Basketball" (YouTube "NBA Extra", 2020). This was the French Kobe, "Notre Kobe", our Kobe, as 5 Majeur wrote (5 M Kobe special issue). This shows the strength of the NBA's media strategy, the power of Bryant's own brand, and the cultural dimension of sportscasting, as it is the site of cultural transfers and the construct of a global culture and imagined communities.

Kobe's media representation reflects several things on the part of 5 Majeur writers: their latent ethnocentrism or chauvinism, their acculturation and Americanization, and their role as cultural mediators. Michèle Gellereau defined cultural mediation as actions to assist audiences in their understanding of cultural productions, and the production of cultural objects and languages to produce meaning and ties, and bridge the gap between culture and audiences (Eyriès, 
2018, 69-70). 5 Majeur's covers and articles played this part, bridging the gap between the NBA and its French audiences by producing representations to help them understand this spectacle. In this regard, special correspondents did play a crucial part in representing the American culture for the French audience through their texts. Their representation of Bryant's life and career did influence the readers' perceptions of them-for better or for worse.

\section{(Toxic) Lessons from the Hardwood: the Dark Side of the Poster Boy's Story}

The prevailing narrative that the French media clung to throughout Bryant's career was summarized by TV analyst Jacques Monclar: "He made people understand that someone could actually play like Michael Jordan" (YouTube "NBA Extra", 2020). Despite the (one-sided) love-hate relationship they had with him, 5 Majeur writers did portray Bryant as a hard-working player who scrapped and clawed his way to legendary status - and the equal to virtually untouchable-mythical figure in Michael Jordan. He conveyed a message of hope, a sort of an athletic version of the "Yes We Can" mantra. Yet this story of hope is problematic in a far more complicated, political context (Berlant, 2011). More generally, while mostly being portrayed and perceived as apolitical, the contemporary global sports spectacle is very much political, and so is its media coverage. Just like other media, 5 Majeur constructed mediated political realities which need to be deconstructed (Nimmo \& Combs, 1990). Beyond hope, greatness, and the celebration of surpassing oneself, the magazine conveyed problematic messages, from the cult of performance to the celebration of toxic masculinity, the downplaying of sexual assault, and the simplification of issues of race.

\section{The Cult of Performance}

First, the Kobe Bryant narrative was composed of constant references to his work ethic, his competitiveness, his performances, and his offensive production. This celebration of production-and-competition-obsessed American sports stands in sharp contrast to the critical content of French freudo-marxist analyses of contemporary sport, which underline the alienation of mass audiences through the sport spectacle (Brohm, 1992). Also, French author Alain Ehrenberg has underlined a shift in western societies toward what he described as a cult of performance (2010). Among the main signs of this cult are the rise of economic and athletic competition, the insistence on surpassing oneself at work or at home, the celebration of the entrepreneur figure, the rise of athletes as symbols of social excellence, the privatization of public life and publicization of private life, and the insistence on producing, to the point of producing oneself. The media coverage of Bryant shows him as a perfect embodiment of these social obligations - and proof of their supposedly successful outcomes. It reinforces social Darwinism and a capitalistic approach to life and sport. 5 Majeur wrote it best, while discussing Bryant's 81-point game: "Basketball is still a sport, and sport is fun when we try to surpass ourselves" (5 M no. 147, 20). Yet, this cult actually puts a lot of 
pressure on the public, and the underlying discourse tells a harsh story-i.e., failure to "be like Kobe" means people did not work hard enough.

\section{Teaching Alpha Males}

Second, by insisting on Bryant's self-constructed "alpha male" identity, 5 Majeur relayed some problematic behaviors which are commonly celebrated in the contemporary sports spectacle, which can be seen as a bastion of traditional manhood, in which power and control are set as ideals (Courtine, 2011). Bryant's narrative went from one of a golden child trying to become a man in a man's league to Kobe being the Man, the ultimate alpha male, "the standard talent, the go-to virtuoso of key moments, the man hated by his peers, feared and misunderstood by the crowd, i.e. the boss" (5 M no. 194, 31). It allowed to construct the figure of a tough guy-a toxic figure to some extent, from its celebration by sports fans (Calman-Lamb, 2018) to the standard it sets for the youth (Bachynski, 2019). 5 Majeur writers celebrated the way he adapted to pain in order to win: "Broken finger, back in shreds, damaged knees... Kobe is still standing. He changes things, he adapts... he assesses the opponents he is facing. And he always finds a way to have the last word" (5 M no. 188). Even when they wrote an article that raised concerns about Bryant's health, the piece ultimately celebrated his feats:

Kobe is walking, so he is playing. . . [when he injured is back] What happened next? Pure Kobe stuff. He refused to be carted to the Dallas stadium. And walked with his 6'6 body to some epic matchup against Dirk Nowitzki and his teammates. Then he hit - as only he could - one or two crucial shots in the closing minutes and found a way to be a factor on the other end of the floor, as if his life or career depended on it.

Are you sure, Dear Kobe, you do not want to take some time to patch your carcass up? The worst part in this is that the Lakers staff is letting him do this, and is looking the other way. Kobe is playing-and he will keep on playing until the day-which we do not want to see happen anytime soon-when he will have to pull over and run to the infirmary $(5 \mathrm{M}$ no. 184,19$)$.

Also, this tough guy image was developed through feuds and rivalries with teammate Shaquille O'Neal—described as “a western spaghetti” (5 M no. 179, 14)—or, to a lesser extent, with LeBron James - a rivalry compared to France vs. the Federal Republic of Germany, or the USA vs. the USSR (5 M no. 177, 19). Bryant had to be the Man-an obsession which was as much the result of his own gender performance as a reflection of the media and writers' want to celebrate an Alpha male. Roland Lazenby even wrote in his Bryant biography that Kobe always wanted to be the Man (Lazenby, 2016, 121-2, 529). He went so far as to say that Bryant was an Alpha Male, as early as age 13. Bryant was also a "bad motherfucker" who used trash-talking to establish his dominance (549). This toughness was also widely celebrated by 5 Majeur, as the emphasis on the Matt Barnes episode shows (5 M HS no. 23). Last, when Bryant was caught calling a referee a "faggot," the magazine wrote 
a signifying article in support of the player, which showed the writers' male gaze, toxic masculinity and difficulty to tackle social issues:

To call a ref a faggot was not a good idea. Especially in a country converted to political correctness. Kobe learnt it the hard way. He should have known better. Actually, he does. Kobe was not born yesterday. He knows that Los Angeles one of the cities where the homosexual community is the most numerous and powerfully organized in the United States - does not tolerate any slip of the tongue anymore. Yet, the lifelong Laker could not help himself. Much hypocrisy surrounds the criticism aimed at Kobe. The past scandals were brought forward to accuse Kobe with all the evils on earth.

The career of the best basketball player since Michael Jordan's retirement has never been a long, quiet river. Of course, there is some hypocrisy in all this. For the bad word used by Kobe is actually pronounced millions of times each and every day on the playgrounds of the five continents. Is it a good thing? No. Are gay people right not to want to put up with these language excesses? Certainly.

But Kobe does not deserve to have to face once again the outraged reactions of an all-too-nitpicky press, and a community which is constantly expressing ridiculous demands. A few days after the incident, Kobe started playing crucial playoffs which could take him to the same level as Michael Jordan. That is what we care about (5M no. 196, 20).

As Bryant's Alpha Male/tough guy persona was set as an ideal to the readers, one could argue that this performance of a certain manhood mixes the Black mask or cool pose (Majors \& Mancini Billson, 1993) — itself a signifying element related to Bryant's identity - with toxic behaviors such as homophobia and violence, attached to hegemonic masculinity (Connell, 1995, 76-86). For more than 20 years, 5 Majeur has told its readers that occasionally, being an arrogant bully and playing through pain was cool, especially if you were dominant and winning - a problematic lesson to teach, and yet a reflection of gender performances of these times, and of masculine dominance in both France and the USA (Bourdieu, 1998). And this is only part of the gender-related problematic messages conveyed by the magazine.

\section{The "Colorado Mistake"}

Also related to issues of gender and toxic masculinity, 5 Majeur's coverage of the sexual assault case in Eagle County, Colorado, raises many issues. When the news broke, the magazine's writers went from dismay to disgust, and doubt. For many years, the opening editorial had been written in the form of a dialogue between two NBA fans. In the summer of 2003, these dialogues gave voice to two statements: one who raised doubt over the alleged victim's statement, and one who reminded the readers that the accusations were serious. In issue no. 122, the editorial insisted on athletes' responsibilities as role models, insisting that "Basketball players [were] not above the law" (5 M no. 122, 3, 31, 37). The writers also underlined the high stakes faced by Bryant, and portrayed him as a victim: 
This fight is a bit uneven. On the one hand, a man exposed to the crowd's eyes, judged before the justice system even took a look at the case. On the other hand, a young woman, anonymous — almost—defended by authorities-which is normal. . . trial or no trial, Kobe has already lost. He lost the esteem of many Americans, and the trust of the majority of his sponsors. A presumed wolf thrown in the middle of a sheepfold filled with hypocrites. Kobe will be alone, then (5M no. 122, 30).

The following issue underlined the writers' fan-boy identity and their lack of objectivity and implied disbelief at the alleged victim's accusations:

All these miscellaneous news, that's next to nothing. / Rape, next to nothing? / Kobe did not rape. Maybe he pushed, at the most... / This thing stinks! / Close your eyes and imagine Kobe. Have you ever been near him? I have. This guy is a falcon, a vine. The Eiffel Tower, only better. / He is a great basketball player. But he is a lost human being, a wreck. (...) I'm not anti-Kobe. No, I am close to him. I would like to see him get out of this. I feel sorry for him, with this lawsuit hovering over his head (5M no. 123, 4).

They also insisted on protecting Bryant, in a sharp contrast to their lack of consideration for the alleged victim: "It is the duty of Phil Jackson, and, by extension, the franchise managers to protect their player... Now, the most important thing is Kobe's physical and psychological well-being" (5 M no. 123). Then, they called attention to the impact of the scandal on Bryant's career and urged him to defend himself using more than questionable analogies:

Kobe is Kobe. Not some sneaky guy. Only some hermit. Not some conceited guy. Only a loner. Not some gangster. Only a guy that's too famous, too seen, too exposed, too abused... Kobe must go all the way. Defend his honor and hope that a popular jury will be convinced by his smile of injured animal. He is still the wild beast we know - hungry, awesome, so helplessly selfish and full of panache (5M no.124, 33).

The next move was to actually see in Bryant a rebel who distanced himself from self-righteous America - a stand the French writers appreciated:

As if he was caught up by all those years he sacrificed on the altar of some maniac, borderline psychotic professionalism, the façade of superman Kobe ended up cracking and busting in the face of the public after some nightly misconduct in a hotel room in Colorado which made the news all around the world. A great, ridiculous live spectacle like only America dares offer the world ... Kobe ended up telling the establishment to get lost, to at last become a free man, at the risk of displeasing self-righteous America. He is not alone on the Stations of the Cross. Kobe used to not be afraid of anything. Today, he has become human (5M no. 125, 60).

In time, the writers ended up supporting the player, and underlining his courage throughout the process - and his unbelievable athletic talent in the face of adversity which led to him being compared to Jordan, "only better" (5 M no. 129). The assault 
was turned into some "mistake," "miscellaneous news," and some "obstacle" Bryant had to overcome (5 M no. 129). To sum this up, the case was used to celebrate Bryant's athletic feats even more-something which can be also found in Mark Heisler's book on Bryant and the Lakers, as the Los Angeles Times writer described him as "born again," basically portraying him as "an outcast" (Heisler, 2009, 53) and "a martyr" (73), as Bryant discusses being "crucified" by the media (66). And later, the writers went on to support Bryant throughout his redemption process, criticizing the hypocrisy of the American media and society, and being in awe of Bryant's courage in a "me-against-the-world" narrative. This "episode" actually made Bryant even more deserving when he won two more titles in 2009 and 2010:

The time has come to celebrate Kobe's genius with no restraint. It is an understatement to write that the career of the 2009 NBA Finals MVP has not been some long, quiet river. It was more of a mountain stream, boiling from feats and endless challenges (5M no. 179, 14).

Only a few NBA players - except for Bill Laimbeer, maybe-have been as hated as him. What does the crowd reproach him with? What people think they know, what they have heard somewhere... In turn, Kobe has been a conceited rat, a bad teammate, an alleged rapist (the Denver case...), a potential traitor (hearsay had it that he wanted to leave LA), a ballhog... Kobe has seen, read and heard everything. And yet he is still standing. (...)

Kobe is NBA champion. No one deserves this more (14).

5 Majeur then simplified the narrative to insist on some return to normal in stark contrast to the 2003-2004 issues, symbolically turning Bryant into some potential sexual beast again, as if the scandal and its aftermath had deprived him of his manliness: "The same public which stayed away from him because of his selfish behaviors and repeated appearances in the daily miscellaneous news, has now wiped his slate clean. Kobe has become some kind of ideal son-in-law and dreamt lover again" (5 M no. 156, 22).

After his death, while the American media were quick to question his complicated legacy, 5 Majeur painted a less nuanced portrait. Only a small stain remained, in the shape of a short note entitled "The Tarnished Image" (5 M HS no. 23, 60), illustrated by a mini-portrait of Bryant and his wife Vanessa Bryant at the nowfamous press conference where she sat next to him while he discussed the accusations: "The Laker player entered the miscellaneous news section in July 2003 when he was accused of sexual assault by a 19-year-old young woman in Colorado. This case would come to be followed closely by the American people, and it would have an impact on his career, as well as his way of being and his personal life.... His image was significantly tarnished, to the point where he had to release a statement to publicly express his apologies and his understanding of the plaintiff's feelings and pains" (60). While the magazine rarely tackled social issues-apart from some occasional statements on racism and social inequalities in America-the coverage of the Colorado case actually nourished the blaming of or lack of support for sexual assault victims. It also downplayed the event as a "mistake" (5 M no. 125, 57) which could be explained by the solicitations received by athletes like Bryant: 
The women who hover around them are seduced cheerleaders, groupies who would do anything to end up in their bed, female press agents and reporters who fight to be in their company. Every single moment of the day, apart from practices and games, is made of barely veiled temptations, sexual innuendos and wry smiles. After a few years of this, how would they not think they could do whatever they want? Even using a little violence when a young woman is resisting you... Kobe is not the first athlete to fall into the trap awaiting every famous athlete (5M no. 122, 36)

Yet this assessment goes beyond sports media. Most French scholarly works mentioning Kobe Bryant focus on the Public Relation side of the case, and how he and his sponsors managed to handle the image crisis this case represented. From the 5 Majeur pages to academic journals, the shift to the Black Mamba narrative was celebrated as a brilliant move by Bryant and his endorsers-and discussing of gender, sports, and society did not cross the Atlantic, as well as another sensitive topic in both France and the USA-race.

\section{Complex Yet Simplified Identity}

In the USA, most academic works citing Kobe Bryant or tackling his sexual assault case delved into issues of race. Anoop Mirpuri discussed Bryant as "a cultural symbol that has been shaped by, and contributed to, the terms by which 'race' is read and deployed in popular discourse" (2011, 97-98). He also described the NBA as "the fulfillment of America's universalist project, at the same time as symbolic figures of racial difference are constructed within narratives that serve to maintain racial borders" (98). In his work tackling the relation between basketball, race, and popular culture, Todd Boyd described Kobe Bryant as "the NBA's de facto white man" for his identity as an upper-middle-class African-American teenager who grew up in Europe-a sharp contrast to inner-city kids, as in the case of Allen Iverson and others $(2003,161)$. He added that his behavior at the press conference during the Colorado scandal made him look like "a 'Lil bitch', defying every imaginable code of Black masculinity," which raises issues of race and gender $(2003,167)$.

Interestingly, Bryant, throughout his career, came to embody several Black masculine bodies as identified by Ronald Jackson, from the vicious criminal to the sexual superman, the superior athlete, and the perfect entertainer $(2006,24)$. Yet, 5 Majeur eluded this issue. They portrayed Bryant as a prodigy, a smiling, golden boy who stood in contrast to the rebellious Allen Iverson. If their social origins were mentioned, they were mostly linked through the city of Philadelphia and represented as rivals with two different approaches to the game of basketball—not as two versions of some fantasized Black America, at least not openly. 5 Majeur was selling its product through black players with strong identities: Michael Jordan as the Greatest, Kobe Bryant as his Heir, Vince Carter as the Dunker, Allen Iverson as David facing Goliaths, and Tony Parker as the Frenchie living the American Dream. ${ }^{5}$ While

\footnotetext{
5 See the covers of issues no. 106, 107, and 120.
} 
Bryant was described as an ideal son-in-law, he was not portrayed as a crossover figure who succeeded thanks to his more acceptable African-Americanness. As a reflection of the period, the magazine focused on entertainment and the celebration of the (African-)American culture through basketball. Written by open-minded, politically conscious writers (as the recent articles on LeBron James and the Black Lives Matter movement demonstrated), the articles on Kobe did not mention raceexcept for one article on the Colorado trial, when the writers mentioned race as being a potential factor in the trial, as Bryant would have faced an all-white jury: "Kobe will be alone, then. Alone with his conscience. Alone against everybody-or so. $84.5 \%$ of Eagle County inhabitants, where he will be judged, are white. And this is not good news for him, for sure. For his victim is white" (5 M no. 123, 31). Now, not mentioning or tackling race can be read several ways: as a reflection of the French tendency not to discuss the matter and pretend it is settled, as a want to portray the NBA as a post-racial ideal in which racial equality has been taking place throughout the period, or a privilege of perceiving the NBA spectacle as mere entertainment. In any case, Kobe Bryant's racial identity has been left aside by 5 Majeur. This erased part of his complexity as a sign.

This analysis shows that, even in a basketball magazine, the Kobe story was about more than basketball. While trying to avoid controversy and politics, 5 Majeur did not portray what they wanted to portray-i.e., some apolitical poster boy. They actually represented a signifying, latently political figure, a myth naturalizing the political (Barthes, 1957). Kobe's representation in the French media reflected today's global sports spectacle as bastion of traditional manliness, and conservatory of toxic masculinity. It also revealed the struggle to tackle issues of race and gender, or the will not to do so. Overall, the common elements and differences in the media coverage of Bryant in both France and the USA gave birth to a global icon with mostly shared meaning. Yet, these differences in meaning are signifying, for they shine a light on today's critical issues regarding communication in sport and society.

\section{Global Icon, Evolving Meaning: the Readings of Kobe Bryant and Changing Communication in Society}

Throughout Kobe Bryant's career, French fans could follow his adventures through media. It started with magazine articles and once-a-week televised games. It then evolved to daily Internet articles and game summaries, and then daily televised games. On April 13, 2016-or the early hours of April 14 in France-they could follow a play-by-play of Bryant's performance, while also receiving reactions from American media and fellow Laker fans live. This very day stood as a great example for the evolution of the NBA's communication scheme. The league had become global, and social media helped it sell its stars abroad. They also gave more visibility to other discourses - a true illustration of Henry Jenkins' transmedia storytelling (2006). As Dues and Brown wrote, "New technologies have made it easier for people to communicate across both space and time, and people can join in communities of interest, rather than communities of place" $(2004,85)$. On this day, French fans were invited to Staples Center to witness Bryant's last performance along with millions 
of NBA fans around the world. The "imagined community" of Bryant's fans knew no distance between its members anymore. And at that particular moment, Bryant's meaning was universal - to them. Yet, on January 26, 2020, the scene was way more complex, as were the discourses displayed on social media. In the rapidly evolving world of media and communication which Bryant was tied to his entire career, it is interesting to assess the relation to "Kobe" as a sign and text. What does the representation of Bryant both in France and the USA tell us about communication in these societies? How has his representation evolved over time? To which extent did the evolution of media and communication impact the evolving representation of Bryant as sign?

\section{Soft Power: the Kobe Story and American and French Ethe}

The Kobe Bryant story illustrates the political dimension of sportscasting, especially in relation to international politics. Subtly or not so subtly, Kobe came to embody America's soft power in and for the eyes of French fans. Joseph Nye defined soft power as some attractive power which rests on the ability to shape the preferences of others, using several resources such as culture (Nye, 2004, 5-6). He also underlined Michael Jordan's role in producing American soft power (17). While Jordan did play such a part, Bryant also did, at a critical time in the history of the NBA, the media, and communication. At a time when information traveled faster and more directly to audiences all around the world, Bryant was turned into a global icon. His portrayal as Team USA's leader at the 2008 Olympics (5 M no. 179, 16), and the reaction to his death around the world, and especially in China, Spain, and France (5 M HS no. 23, 13), places the NBA "culturally invaded" efficiently showed this. In a country where the most iconic teams and athletes were mostly low key, lower-class champions, or romantic runner-ups, Kobe was sold as an ideal to emulate-and it worked, to the point that he was used as an ideal in comparison to failing French soccer players in 2010 (5 M no. 188, 26). Also, his performance- and productionobsessed approach has had a profound impact on the psyche of the French audiences and athletes over the last 20 years. This can be seen through the publication of Bryant's book The Mamba Mentality: How I Play in French in 2019. Bryant's soft power influenced the French ethos, which is appreciably different than that found in America (Durbin, 2018). He is proof that French audiences are susceptible to being Americanized through culture and media representation. This reflects Billings, Butterworth, and Turman's words on how sport is used to communicate-and thus affirm and extend-American values $(2012,7)$, and how interactions through sport and communication can lead to an enhanced form of identification (59). The French audiences have experienced some kind of acculturation, as Roger Bastide would describe $(2000 ; 2001)$, as they took up some elements of the American culture through Bryant. David Sudre showed the impact of the NBA on French playground players, and how they proudly became "Cainris"-or Americans in French slang (2013). Among the NBA jerseys Sudre could find on these playgrounds, Bryant's was among the favorites. In relation to this cultural process, the media's part 
needs to be underlined. They can be seen as physical or virtual gateways of globalization (Espagne, 2012). And the evolving media coverage of Bryant has helped turn him into a global sign and sell the American Dream-which was actually the title of the NBA weekly show on French television for some years. Yet, the different media did not exactly play the same part, nor they had the same impact.

\section{Kobe, a (Mediated) Life: the Part Played by Traditional Media in Telling a Unifying Kobe Story}

While they did not do the exact same job, French television networks and magazines which covered the NBA were mostly doing the same thing, i.e., sell the NBA and American Dream to the French audiences. This is linked to the identity of sports media as entertainment, as well as the writers and announcers. On television, French American broadcaster George Eddy has been the voice of the NBA on Canal Plus since 1985, the start of the NBA's invasion of French television. While he was occasionally critical of the NBA, he was mostly known for his thick American accent and his over-the-top enthusiasm for the league and its stars. When the NBA moved to Bein Sports in 2011, the main announcers were Eddy's former play-by-play colleague and disciple Xavier Vaution, and host Rémi Reverchon, who had spent years covering the NBA as a special correspondent from Los Angeles, where he developed a deep love for Kobe Bryant-a feeling he never shied away from on air. As far as monthly magazines were concerned, among which 5 Majeur stood as a main reference, articles were mainly written by already-Americanized special correspondents who commented upon and mostly relayed the American media stories. Even though they could be occasionally critical of the American sports spectacle, the French media usually told simplified stories that either unified audiences or created strong dichotomies in the form of morality plays, prompting the audience to choose sides. While morality plays stage Good versus Evil, Bryant alone was a morality play. This led to his extensive media coverage. So, the NBA's and the American media's transmedia storytelling strategy was mostly relayed, and sometimes simplified, by the French traditional media. And the Kobe Bryant story lasted for more than 20 years - up until the coverage of the Los Angeles Lakers' title in 2020, which they "won for Kobe," as the television announcers and 5 Majeur writers stated (5 M no. 289). In a sense, throughout Bryant's career, the pages of French magazine 5 Majeur or the NBA shows on television could be seen as heterotopias as defined by Michel Foucault (2009). Indeed, they have been particular spaces where communication is established, and common meaning is set. Apart from reality, there have been counter-spaces where the Kobe story was mainly neutralized, purified, or idealized, where audiences were trained to learn a new ethos and think otherwise, where multiple spaces were juxtaposed, where time was handled differently, and with opening and closing systems. By sharing these heterotopias, French audiences shared common representations of Bryant and the NBA. They stood as an imagined community, reading and listening to the same story. Yet, as Denys Cuche wrote, mass culture and communication do not translate into "cultural uniformization" and "the uniformization of the reception of messages" contained in these potentially unifying stories, as 
humanity keeps on "producing cultural difference" (2010, 86-88). The rise of other media highlighted this fact, and a shift toward the production of counter-narratives.

\section{Redefining the Game and the Story? The Impact of Social Media on Sport, Communication and Memory}

Social media has had a great impact on communication, both in France and the USA. Among the main impacts social media has had, the rise of engagement and production of messages and meaning by other sources than the NBA itself or traditional media has altered the landscape. Emilio Fernandez Peña wrote that new media "allow users to change messages and to create new messages" $(2011,143)$. This new engagement can actually help turn users into "advocates" for a league or an event, who would spread "certain values and ideals to other members of [their] social network," as he showed with the Olympics (150). Actually, social media has had a dual impact on the NBA's transmedia narrative. On the one hand, it has strengthened its brand and anchored its stories, as the rise of French websites and social media accounts relaying the American media's stories such as TrashTalk proves. Yet, in the meantime, it has given a voice to the voiceless, and visibility to other discourses. As storytelling can be seen as a tool for communication, control, and power, so the rise of social media and counter-narratives has led to some loss of control on the part of the NBA and traditional media, over message framing (Ahmad, 2012, 59).

As William Benoit and Andrew Billings underlined, social media has led to the fall of mass communication, meaning that building and spreading a unifying story gets more and more difficult (2020). The social media coverage of Bryant's death shows exactly that. While the French traditional media were on the same, unifying page, French audiences could also read tweets by American media, scholars-or layperson-underlining Bryant's complex legacy, something that was absent in the French media. While social media allowed athletes such as Bryant's to build a stronger brand, resulting in a global audience, it also opened the door to less control over the narrative of his life. Counter-narratives appeared, mostly underlining the need to confront Bryant's past as someone accused of sexual assault. On April 13, 2016, social media helped unify Kobe fans by promoting the idea of sporting events being shared experiences (Billings et al., 2012, 298). On January 26, 2020, social media offered French audiences a different, more nuanced story on Kobe Bryant's life. The Kobe Bryant study case helps us understand this important development in communication.

\section{Players' Agency: the Rise of the Player's Control Over His Narrative}

Throughout their history in the NBA, African American players have understood the need to control their own narrative. Julius Erving underlined the necessity for African American athletes to represent themselves carefully in interviews 
to counter racist stereotypes about African American athletes (Mallozzi, 2010, 32). Through interviews, and mostly through autobiographies, African American NBA players have tried to redefine their stories and seize control over them. Now, social media stand as new spaces for self-representation (Lund et al., 2018, 275), and thus new tools to seize this control. With a career spanning from the rise of the Internet to that of social media, and the explosion of endorsements, Kobe Bryant took self-representation to new heights by setting his own meaning as a sign himself. Indeed, in the aftermath of the Colorado case and the end of the Shaq-and-Kobe era in Los Angeles, Bryant changed his jersey number and gave himself a nickname, "Black Mamba." He seized control over the representation of him. In the process, he developed some form of ideal athletic masculinity and created new meaning. He did so by relaying and amplifying a closely crafted narrative through multiple means, from advertisements with Nike, to film (Spike Lee's Kobe Doin' Work and his own Kobe Bryant's Muse and Academy-award winning short film Dear Basketball), to his book (The Mamba Mentality: How I Play) and his children's book (the Wizenard series), to his basketball academy (the Mamba Academy), and his social media posts.

In his book, Bryant defined the so-called Mamba Mentality as "a mindset" (Bryant, 2018 , 93). He wrote about his "Biblical workouts" which "have become a thing of legend" (25-26). He underlined how he managed to play through pain (68), also marking his ruptured Achilles as a key date in his life, next to his draft, his championship titles, the 2008 Olympics, or his last game. More signifyingly, in the Wizenard series, Bryant basically laid out the Mamba Mentality's philosophy in the form of maxims or proverbs (Bryant \& King, 2019, 571-575) and offered advice to the youth which illustrates his own effort: "Never let your identity be written by another" (571). Regarding social media, he used them as a branding tool, crucial to control his online identity, as Korzynski and Paniagua would argue (2016, 186). More signifyingly, he used them as "spaces for self-representation" and "spaces for staging performances" (Lund et al., 2018, 275) and presenting his new constructed self, as social media allowed him to (Billings et al., 2012, 147).

Just like any human being, Bryant evolved over time, turning into a family man, supportive of his daughter Gianna's love of basketball, and thus becoming an advocate and support of the Women's National Basketball Association. Last, he invested on the website The Player's Tribune, showing his interest in athlete-controlled media platforms. He also made a point in telling the media that basketball did not define him (L'Équipe no. 23,924, January 27, 2020), that it was what he did, and not who he was (YouTube "NBA Extra", 2020). He understood the power of storytelling to provide meaning to his brand and enhance the audience's connection with him (Singh \& Sonnenburg, 2012). Last, he made a point in avoiding issues of race, insisting on his work ethic more than his identity, as he told Dime magazine, "What separated me from others more consistently than skin color or age was my hunger. My mission" (Heisler, 2009, 60). His non-insistence on race, combined with his identity as an upper-middle-class African-American man in a league filled with African-American men from the inner cities, actually led to a few episodes in which he was criticized for not being politically involved enough (Adande, 2014), like with his social media exchange with former football player Jim Brown (Weinreich, 2013). 
In retrospect, Bryant's evolution regarding his handling of his public persona reflects the athletes' growing control and power over their representation and the narrative developed around their lives and careers. In a media scene where traditional media turn more and more to storytelling in response to the immediacy of information, and where social media allow for the rise of multiple discourses instead of one monolithic story, athletes can represent themselves. Bryant did it and claimed authenticity. Jacques Gerstlé wrote that "the efficiency of political communication also depends on the cultural acceptation of produced messages and the legitimacy of the message producer" (Eyriès, 2018, 55). In the social media world, no one seems to be more legitimate than the athlete to tell his truth. Bryant wrote how he wanted to "keep it real" with the media, and how being "authentic" made fans and reporters appreciate "the real [him]" $(2018,78)$. He understood that with more sincerity, "fans would become more loyal" (Fernandez Peña et al., 2011, 150). His fans turned directly to him instead of his media portrayal. He thus had more control over his public persona, and he used it efficiently, building a new narrative and brand. This reflects the evolution of an evolving character, conscious of the fact that he was also a global product (Lazenby, 2016, 535) playing in a global drama, and who became interested in storytelling (573-4) and control over the narrative (530-2). This social media self-representation of athletes is still very much constructed-a performance of the self and masculinity (White, 2011). Still, what matters here is its political significance. In a history of racially stereotyped media representations, the rise of a counter-narrative controlled by African American athletes is signifying. Autobiographies used to serve this purpose. Social media have now emerged and allowed a power shift in the representation of athletes. With his use of multiple platforms which he could control, Bryant seized power over his own narrative, thus standing as one more voice in the crowd-but the most impactful one.

From a communication standpoint, Kobe Bryant's life and career and its signifying media coverage reflects a critical time. It shows the NBA's burgeoning political power in relation to international politics, as Bryant became the athletic flag-bearer for well over a decade, the symbol of the American ethos, and a cultural tool to influence foreign audiences like the French. It showed the changes in the communication scheme around the NBA, as the league and traditional media's power in constructing and spreading main storylines, and thus, controlling the discourse around their product has been challenged by the birth of social media, leading to the rise of counter-narratives - and more complex stories.

\section{Discussion}

Great athletes do not automatically make for great stories. But Kobe Bryant did. At a time when the NBA's globalization shifted gears, he was the heir to the greatest global basketball story ever-Michael Jordan. He went from being the kid in a man's league trying to become a man, to becoming the Man. In the process, he became a global sign-or at least a sign shared in the NBA-watching world. His celebration around the world showed the power of the NBA, the media, and shoe companies' transmedia storytelling. His own use of social media, film and books 
helped him gain control over his meaning. Yet, his death showed the different meanings people attached to him, and it unveiled a fractured society, especially in regard to gender issues. Cornog wrote about the importance of stories in the American context: "From George Washington on, the success of every president has depended on his ability to build consensus for his narrative, and to persuade the press and the people to accept his story line. (...) These crafted narratives are the principal medium of exchange in our public life, the currency of American politics" (2004, 2). Bryant's story - the one the NBA and the media produced, the one he himself crafted, and the ones developed on social media-is a reflection of the power of stories in the context of sports, and their latent political dimension.

Mostly portrayed as a crossover hero of a mostly apolitical narrative, Bryant was in fact a truly political myth. Raoul Girardet wrote that "myths are coded stories and deformation of reality which need to be deciphered. These myths allow some kind of 'mental restructuring' to understand the present and gather communities together" (Girardet, 1986). Deciphering the Kobe story allows one to unveil a reality marked by capitalism, toxic masculinity, and issues of gender and race. This leads to question the part played by magazines and traditional media in selling a meaning-deprived sports spectacle. Indeed, 5 Majeur's coverage of Bryant is signifying in that respect, as it simplifies a complicated story, the way other media companies have done, like ESPN owner Disney. Alan Bryman defines the process of Disneyfication as "to translate or transform an object into something superficial and even simplistic" (Bryman, 2004, 5). Wasko insists on a process of "sanitization and Americanization" (5). Bryman added that to Disneyfy meant adding layers of fantasy (8-9), and that it was "associated with trivialization and sanitization" (5-6). In a sense, the Kobe story in French magazine 5 Majeur came close to this process, as it mainly simplified, sanitized, and trivialized Bryant's story, particularly at the time of his death. And while they occasionally criticized Bryant, the sports spectacle, or America, they were building their own brand, i.e., the "We know better" French magazine giving its audience the "true" NBA, thus reflecting the history of the France-USA intellectual relationship. In that case, Bryant was a "5-Majeurized" figure-occasionally criticized by his fans, yet very much embodying their ultimate fantasy. They told the Kobe story from a different perspective, yet this perspective was very much influenced by the NBA, American media, and Bryant's own storytelling. And while the French writers claim to be more objective toward the American sports spectacle, they have been very much infatuated by their product-their rhetoric actually reflecting the NBA's soft power and the writers' Americanization.

Media influence audience's thoughts, attitudes, and behavior (Dues \& Brown, 2004, 72-73). As Sudre showed, global signs like Bryant have an impact on the people's psyche and culture (2013). They influence audiences, and thus the meaning media set for them, or the meaning they set for themselves, need to be assessed. To the French audience, the Kobe story was turned into a mediated reality deprived of the political. And yet, this story was very much political, as the part played by social media in the new global world of sports is. Indeed, while social media could have led to more communication and a wider outreach, they led to a change in communication. As Benoit and Billings showed, mass communication is being replaced by a balkanized communication. The reaction to 
Bryant's death on social media revealed his global impact, just as much as it revealed the part played by traditional media in simplifying his story and legacy, and the one played by social media in complexifying it and relaying counter-narratives. As Fiske showed for television, social media have played a crucial role in the social circulation of discourse and thus in potential social and political change (Fiske, 1999, 10), as "it produces knowledge and applies power" (217).

Social media can be a gateway for globalization. It can also help fight Americanization and the simplification of stories on public figures, as well as on a country and its culture. Also, the evolving meaning of Bryant is as much the result of his own evolution and the evolution of sports, media, and communication over time, as it is the reflection of these times. The gap between the 5 Majeur coverage of the Kobe story and the multiplicity of more complex discourses shared about Bryant after his death shows another critical issue, which is the rise of new gazes and sensitivities in tension with the sports media-relayed male gaze. While 5 Majeur can represent some kind of heterotopia of traditional sports (toxic) masculinity and the American Dream, social media now creates multiple heterotopias for everyone to construct by following like-minded people and build their own social-mediated realities - and not communicate with others nor share common meaning.

\section{Conclusion}

The coverage of Kobe Bryant shows a broken communication, and a diversity of perceptions-something which goes beyond sport. History is another topic on which people argue over the meaning of events and figures. Both France and the USA are experiencing issues related to some broken communication among national imagined communities over the meaning of their icons. Both countries struggle to bridge this communication gap and find unifying stories, especially in regard to issues of gender and race. Just as Cook showed about the relation to the Civil War in the USA (2017), the relation to Bryant and his meaning may evolve with time, depending on the context. And just like with traces of the Civil War in American public spaces, his future presence in streets named after him, or as a statue next to Staples Center might lead to signifying debates further reflecting the communication gap. It already does (Holter, Estrada \& Echeveste, 2020). The Kobe Bryant story is not over. Cornog wrote that "stories are the tools we all use to bring order to chaos. Stories are where facts gain meaning" (2004, 3). Yet recently, they have had the exact opposite effect. Nimmo \& Combs $(1990,18)$ underlined the necessity to deconstruct our mediated political realities:

Mediated, secondhand reality is our politics, and there is little we can do about it. But we can examine our own and others' political fantasies with an air of skepticism, learning to be wary of what we might otherwise take for granted. There is at least some liberation from the cave of fantasy in that. 
Maybe a complex story is not bad, after all. It says a lot about our times. What matters is reestablishing communication and dialogue and deconstructing our fantasies.

\section{References}

5 Majeur \#85-291.

5 Majeur Hors-série \#8-25.

@ kobemurals, Twitter.com. https://twitter.com/kobemurals. Accessed 7 Jan 2021.

Adande, J.A. (2014). “Kobe, Trayvon, and Black Twitter.” ESPN.com. 29 March 2014, http://espn.go. com/nba/story/_id/10695273/kobe-bryant-trayvon-martin-black-twitter. Accessed 1 Jan 2021.

Ahmad, T. (2012). An analysis of how National Basketball Association (NBA) teams use social media. Published Doctor of Philosophy dissertation, University of Northern Colorado.

Andrews, D. L. (2001). The fact(s) of Michael Jordan's blackness: excavating a floating racial signifier. Pp. 107-152 in Michael Jordan, Inc. Corporate Sport, Media Culture, and Late Modern America, edited by D. L. Andrews. New York: State University of New York Press.

Archambault, F., Artiaga, L., \& Bosc, G. (2007). Double Jeu, Histoire du basket-ball entre France et Amériques. Vuibert.

Bachynski, K. (2019). No game for boys to play: The history of youth football and the origins of a public health crisis. The University of North Carolina Press.

Baily, A. A. (2007). Public information and consumer skepticism effects on celebrity endorsements: Studies among young consumers. Journal of Marketing Communications, 13(2), 85-107.

Barthes, R. (1957). Mythologies. Seuil.

Barthes, R. (1982). L'obvie et l'obtus. Essais critiques III. Seuil.

Bastide, R. (2000). Les Amériques noires. L'Harmattan.

Bastide, R. (2001). Le prochain et le lointain. L'Harmattan.

Benoit, W. L., \& Billings, A. C. (2020). The Rise and Fall of Mass Communication. Peter Lang Publishing.

Berlant, L. (2011). Cruel Optimism. Duke University Press.

Billings, A. C., Butterworth, M. B., \& Turman, P. D. (2012). Communication and sport: Surveying the field. Sage Publications.

Birrell, S., \& McDonald, M. G. (2000). Reading sport: Critical essays on power and representation. Northeastern University Press.

Bolter, J. D., \& Grusin, R. (1998). Remediation: Understanding new media. MIT Press.

Bourdieu, P. (1998). La domination masculine. Seuil.

Boyd, T. (1997). Am I black enough for you? Popular culture from the 'hood and beyond. Indiana University Press.

Boyd, T. (2003). Young, black, rich and famous: The rise of the NBA, the hip hop invasion, and the transformation of American Culture. University of Nebraska Press.

Brohm, J.-M. (1992). Sociologie politique du sport. Presses Universitaires de Nancy.

Bryant, K. (2018). The Mamba mentality: How I play. MCD.

Bryant, K., \& King, W. (2019). The Wizenard series: training camp. Costa Mesa, California: Granity Studios.

Bryman, A. (2004). The Disneyization of society. Sage.

Connell, R. W. (1995). Masculinities. Polity Press.

Cornog, E. (2004). The power and the story: How the crafted presidential narrative has determined political success from George Washington to George W. Bush. The Penguin Press.

Cook, R. J. (2017). Civil War memories: Contesting the past in the United States since 1865. John Hopkins University Press.

Courtine, J. J. (2011). Balaise dans la civilisation. Pp. 461-480 in Histoire de la virilité. 3. La virilité en crise? XXe-XXIe siècle, directed by J.-J. Courtine. Paris: Seuil.

Cuche, D. (2010). La notion de culture dans les sciences sociales. La Découverte.

Dionne, E. (2020). "We can only process Kobe Bryant's death by being honest about his life." Time Magazine. 28 January 2020, https://time.com/5773151/kobe-bryant-rape-case-complicated-legacy/. Accessed 5 Sept 2020. 
Dues, M., \& Brown, M. (2004). Boxing Plato's shadow: An introduction to the study of human communication. McGraw Hill.

Durbin, D. (2018). Unwritten rules and the press of social conventions. Sport, Ethics and Philosophy, $12,416-434$.

Ehrenberg, A. (2010). Le culte de la performance. Pluriel.

Espagne, M. (2012). La notion de transfert culturel. Revue Sciences/Lettres 1. Retrieved September 3, 2020 (http://journals.openedition.org/rs1/219).

Eyriès, A. (2018). Culture, cultures. Le lien social au révélateur. Paris: éditions EMS.

Fernandez Peña, E., Cerezuela, B., Gomez Benosa, M., Kennett, C., \& de Moragas Spa, M. (Eds.). (2011). An Olympic mosaic: Multidisciplinary research and dissemination of Olympic studies. Centre d'Estudis Olimpics.

Fiske, J. (1999). Media matters: race and gender in U.S. Politics. Minneapolis: University of Minnesota Press.

Foucault, M. (2009). Le corps utopique, les hétérotopies. Nouvelles Éditions Lignes.

Franiuk, R., Seefelt, J. L., Cepress, S. L., \& Vandello, J. A. (2008). Prevalence and effects of rape myths in print journalism: the Kobe Bryant case. Violence Against Women.

Girardet, R. (1986). Mythes et mythologies politiques. Seuil.

Hall, S. (Ed.). (1997). Representation: Cultural representations and signifying practices. The Open University.

Heisler, M. (2009). Kobe and the New Lakers dynasty. Triumph Books.

Holter, D., Estrada, W., \& Echeveste J. (2020). “Op-Ed: why L.A. shouldn't rename a stretch of Figueroa street for Kobe Bryant.” LA Times. 6 December 2020, https://www.latimes.com/opinion/story/ 2020-12-06/figueroa-street-kobe-bryant-rename. Accessed 5 Sept 2020.

Jackson, R. L. (2006). Scripting the black masculine body: Identity, discourse, and racial politics in popular media. State University of New York Press.

Johnson, A. R. (2005). When a celebrity is tied to immoral behavior: consumer reactions to Michael Jackson and Kobe Bryant. Pp. 100-101 in NA - Advances in Consumer Research Volume 32, edited by G. Menon \& A. R. Rao. Duluth, MN: Association for Consumer Research.

Jenkins, H. (2006). Convergence culture: Where old and new media collide. New York University Press.

Kalman-Lamb, N. (2018). Game misconduct: Injury, fandom, and the business of sport. Fernwood Publishing.

Kennedy, J. (2010). Image reparation strategies in sports: Media analysis of Kobe Bryant and Barry Bonds. The Elon Journal of Undergraduate Research in Communications, 1(1), 95-193.

King, N., Brennan, C., \& Blackistone, K. (2020). The complicated legacy of Kobe Bryant. NPR. 28 January 2020, https://www.npr.org/2020/01/28/800350329/the-complicated-legacy-of-kobe-bryant?t= 1607595403480. Accessed 5 Sept 2020.

Korzynski, P., \& Paniagua, J. (2016). Score a tweet and post a goal: Social media recipes for sports stars. Business Horizons, 59, 185-192.

L'Équipe \#23,924, 27 January 2020.

L'Équipe \#23,925, 28 January 2020.

L'Équipe Mag \#1,959, 1 February 2020.

Lazenby, R. (2016). Showboat: The life of Kobe Bryant. Little, Brown and Company.

Lee, S. (2009). Kobe Doin' Work [DVD]. ESPN Films.

Leonard, D. J. (2004). The next M.J. or the next O.J.? Kobe Bryant, race, and the absurdity of colorblind rhetoric. Journal of Sport \& Social Issues 28 (3), 284-313.

Leonard, D. J., \& King, C. R. (Eds.). (2011). Commodified and criminalized: New racism and African Americans in contemporary sports. Rowman \& Littlefield Publishers.

Leonard, D. J. (2012). After Artest: The NBA and the assault on blackness. State University of New York Press.

Lund, N. F., Cohen, S. A., \& Scarles, C. (2018). The power of social media storytelling in destination branding. Journal of Destination Marketing \& Management, 8, 271-280.

Majors, R., \& Mancini Billson, J. (1993). Cool pose: The dilemmas of black manhood in America. Touchstone Books.

Mallozzi, V. M. (2010). Doc: The rise and rise of Julius Erving. John Wiley \& Sons.

Markovitz, J. (2006). Anatomy of a spectacle: Race, gender, and memory in the Kobe Bryant rape case. Sociology of Sport Journal, 23, 396-418. 
McDonald, M. G. (2001). Safe sex symbol? Michael Jordan and the politics of representation. Pp. 153-176 in Michael Jordan, Inc. Corporate Sport, Media Culture, and Late Modern America, edited by D. L. Andrews. New York: State University of New York Press.

Meng, J., \& Pan, P.-L. (2013). Revisiting image-restoration strategies: An integrated case study of three athlete sex scandals in sports news. International Journal of Sport Communication, 6, $87-100$.

Mirpuri, A. (2011). Why can't Kobe pass (the ball)? Race and the NBA in an Age of Neoliberalism. Pp. 95-120 in Commodified and Criminalized: New Racism and African-Americans in Contemporary Sports, edited by D. J. Leonard \& C. R. King. New York: Rowman \& Littlefield Publishers.

Monier, B., \& Vivier, C. (2012). L'ère étasunienne du basket français. Étude des représentations culturelles à travers les unes de la revue Maxi Basket. Communication 30/2, Retrieved June 15, 2015 (http://communication.revues.org/3547).

Nathan, D. A. (2013). Rooting for the home team: Sport, community, and identity. University of Illinois Press.

Newberry, L., \& La Ganga, M. L. (2020). For survivors of sexual assault, Kobe Bryant's legacy is complicated. LA Times. 4 February 2020, https://www.latimes.com/california/story/2020-02-04/ kobe-bryant-sexual-assault-survivors-legacy. Accessed 5 Sept 2020.

Nimmo, D., \& Combs, J. E. (1990). Mediated political realities. Longman.

Nye, J. S. (2004). Soft Power: The means to success in world politics. PublicAffairs.

Owens, J. (2020). Kobe Bryant leaves behind a legacy of intensity, greatness, controversy. Yahoo! Sports. 27 January 2020, https://sports.yahoo.com/kobe-bryant-leaves-behind-a-legacy-of-intensity-greatnesscontroversy-011839277.html. Accessed 5 Sept 2020.

Rebillard, F. (2003). La presse basket en France. Évolutions et diversifications des magazines consacrés au basket-ball (1982-2002). Pp. 205-225 in L'aventure des "grands" hommes. Études sur l'histoire du basket-ball, directed by F. Archambault et al. Limoges: Pulim.

Roger, P. (2002). L'ennemi américain. Généalogie de l'antiaméricanisme français. Seuil.

Salmon, C. (2007). Storytelling, la machine à fabriquer des histoires et à formater les esprits. La Découverte.

Singh, S., \& Sonnenburg, S. (2012). Brand performances in social media. Journal of Interactive Marketing, 26, 189-197.

Sports Illustrated Vol. 88 \#17, 27 April 1998.

Sports Illustrated Vol. 99 \#3, 28 July 2003.

Sports Illustrated Vol. 110 \#25, 22 June 2009.

Sports Illustrated Vol. 119 \#16, 21 October 2013.

Sports Illustrated Vol. 129 \#2, 16 July 2018.

Stein, M. (2020). Kobe Bryant's brilliant and complicated legacy. New York Times. 26 January 2020, updated 25 February 2020, https://www.nytimes.com/2020/01/26/sports/kobe-bryant-obituary. html. Accessed 5 Sept 2020.

Sudre, D. (2013). Être “Cain-Ri”. L'appropriation du basket américain en banlieue parisienne. Terrain, 62, 166-179.

Thomas, L. (2020). Anger, love, and the evolving legacy of Kobe Bryant. The New Yorker. 25 February 2020, https://www.newyorker.com/sports/sporting-scene/anger-love-and-the-evolving-legacyof-kobe-bryant. Accessed 5 Sept 2020.

Thwaites, D., Lowe, B., Monkhouse, L. L., \& Barnes, B. R. (2012). The impact of negative publicity on celebrity ad endorsements. Psychology \& Marketing, 29(9), 663-673.

Trespeuch, L. (2014). L'apport du sponsoring de célébrités au capital marque de l'entreprise. Revue Française Du Marketing, 247, 65-75.

Vivier, C., Monier, B., \& Rose, L. (2008). Basketball and cultural representations in the media: An analysis of the French sport magazine maxi basket. International Journal of Sport Communication, 1(4), 487-511.

Weinreich, M. (2013). Kobe Bryant fires back at Jim Brown over comments. SI.com. 12 December 2013, https:/www.si.com/si-wire/2013/12/12/kobe-bryant-nelson-mandela-jim-brown-martin-luther-kinglakers-arsenio-hall-nba. Accessed 7 Jan 2021.

Wenner, L. A. (1989). The Super Bowl Pregame show: cultural fantasies and political subtext. Pp. 157-179 in Media, Sports, and Society, edited by L. A. Wenner. Newbury Park: Sage Publications. 
White, M. (2011). From Jim Crow to Jay-Z: Race, rap, and the performance of masculinity. University of Illinois Press.

YouTube. Kobe Bryant "you showed us" NIKE Ad New 2013. 26 April 2013, https://www.youtube. com/watch?v=_TXXeONnzs0. Accessed 7 Jan 2021.

YouTube. Stade 2 breaks the news of Kobe Bryant's death. 26 January 2020, https://www.youtube. com/watch?v=edBeW55jPSA. Accessed 5 Sept 2020.

YouTube. Bein sports' Sunday Night Live announcers discuss Kobe Bryant's death. 26 January 2020, https://www.youtube.com/watch?v=wWThvfCi5_s. Accessed 5 Sept 2020.

YouTube. NBA extra. 27 January 2020, https://www.youtube.com/watch?v=LLFw_xTyZFE. Accessed 5 Sept 2020.

YouTube. Canal+: a global emotion. 27 January 2020, https://www.youtube.com/watch?v=M8howJ2RIM. Accessed 5 Sept 2020.

Publisher's Note Springer Nature remains neutral with regard to jurisdictional claims in published maps and institutional affiliations. 